\title{
ANALYSIS OF MORTALITY OF PATIENTS AFTER CERVICAL SPINE TRAUMA
}

\author{
By Jerzy Kiwerski, M.D., Marion Weiss, M.D., and Teresa Chrostowska, M.D. \\ Rehabilitation Institute in Warsaw, Konstancin, Poland
}

\begin{abstract}
An analysis of 167 deaths occurring among 1000 patients with cervical spine trauma, treated in the early post-traumatic period in the Rehabilitation Institute at Konstancin, has been carried out in this report.

The high percentage of deaths is caused by the great number of elderly patients suffering from other illnesses, a large group with complete spinal cord injury, many cases of high cervical trauma (above $\mathrm{C}_{5}$ ) and by injuries of other organs, in particular of the skull and chest. We believe that the improvement of general health care in the country taking place in Poland lately, together with the progress in treatment of spinal cord trauma, will bring about a considerable decrease in mortality in the immediate future.
\end{abstract}

Key Words: Cervical spine injury; Mortality.

\section{Introduction}

THE MORTALITY in patients with cervical spine trauma complicated by spinal cord injury is considerable. Most often it is caused by pulmonary complications. After cervical cord injury in this segment, the preponderance of equilibrium disturbances in the vegetative system appear in the sympathetic system and in the vagus nerve (Chorobski, I953; Haftek 1968). This state brings about passive hyperaemia of lungs, increased secretion of mucous glands and transudation of liquid into the alveoli (Rossier 1965; Yashon 1978). With paralysis of the thoracic muscles and, connected with this, the difficulty of deep expiration, the removal of residual secretions is rendered difficult. This situation favours the development of lung oedema, bronchitis, and bronchopneumonia-often the cause of the patient's death. These changes increase at the end of the first and during the second week after trauma, disappearing usually after 4-5 weeks.

\section{Clinical material}

We present the analysis of mortality of 1000 patients with cervical spine injury treated in the Rehabilitation Institute from 1965 to July I979. Table I gives the age of treated patients taking into account mortality in particular age groups. The greatest number of deaths is noted after 65 years of age, and patients who died over 50 years of age constitute 64 per cent of all deaths ascertained. Table II shows the number of deaths in relation to the level of the spinal injury. Cervical spine injuries at the level of $\mathrm{C}_{5}-\mathrm{C} 6$ are most frequent (65 per cent), hence the greatest number of deaths has been recorded with this level of injury. However, a higher percentage of deaths occurred in the smaller number of patients with trauma levels at $\mathrm{C}_{3}-\mathrm{C}_{4}$, at which site, patients with a complete spinal cord injury have little hope of survival. Such patients require intubation and tracheostomy because of extreme respiratory insufficiency from which it is hardly possible to save the patient. 
TABLE I

Mortality in relation to age

\begin{tabular}{cccc}
\hline Age & $\begin{array}{c}\text { Number of treated } \\
\text { patients }\end{array}$ & \multicolumn{2}{c}{ Number of deaths } \\
\cline { 3 - 4 } & & Absolute & $\%$ \\
\hline up to 20 & I34 & 8 & 6 \\
2I-35 & 26 I & 19 & 7 \\
$36-50$ & 22 I & 34 & 15 \\
5I-65 & 248 & 54 & 22 \\
above 65 & I36 & 52 & 38 \\
Total & I000 & I67 & I7 \\
\hline
\end{tabular}

TABLE II

Mortality in relation to the level of spine injury

\begin{tabular}{cccc}
\hline $\begin{array}{c}\text { Level of } \\
\text { injury }\end{array}$ & $\begin{array}{c}\text { Number of treated } \\
\text { patients }\end{array}$ & \multicolumn{2}{c}{ Number of deaths } \\
\cline { 3 - 4 } & 77 & Absolute & $\%$ \\
\hline $\mathrm{C}_{1}-\mathrm{C}_{2}$ & $2 \mathrm{I} 6$ & 9 & $\mathrm{I} 2$ \\
$\mathrm{C}_{3}-\mathrm{C}_{4}$ & 652 & I & 24 \\
$\mathrm{C}_{5}-\mathrm{C}_{6}$ & 55 & 6 & I I \\
$\mathrm{C}_{7}-\mathrm{D}_{1}$ & I I \\
\hline
\end{tabular}

The relatively small number of deaths with injury level at $\mathrm{CI}_{\mathrm{I}}-\mathrm{C}_{2}$ is explained by the fact that in this group there are many patients with minor neurological disturbance. Patients with complete spinal cord injury at this height perished-as a rule-before reaching the special department.

The mortality in groups with different degrees of neurological disturbance (taking into account the classification given by Frankel), is presented in Table III. A study of this Table shows that surgery has no influence on the lethal results. Undoubtedly, the highest mortality occurs in the group with complete spinal cord injury. The large number of patients with this injury treated in our Institute, demonstrates the rather high overall mortality, amounting to I7 per cent.

TABLE III

Mortality in relation to (a) the degree of neurological abnormality, and (b) treatment with or without a surgical operation

\begin{tabular}{crrrrr}
\hline $\begin{array}{c}\text { Neurological } \\
\text { status }\end{array}$ & \multicolumn{2}{c}{$\begin{array}{c}\text { Number of treated } \\
\text { patients }\end{array}$} & \multicolumn{2}{c}{$\begin{array}{c}\text { Number of deaths } \\
\text { after treatment }\end{array}$} & Deaths \% \\
\cline { 2 - 5 } & conservat. & surgic. & conservat. & surgic. & \\
\hline A & 272 & I48 & II6 & 25 & 33 \\
B & 53 & 42 & 6 & 3 & 9 \\
C & IO8 & 79 & I2 & 4 & 8 \\
D & II3 & 98 & - & I & 0,5 \\
E & $5 \mathrm{I}$ & 36 & - & - & 0 \\
Total & 597 & 403 & I34 & 33 & I7 \\
\hline
\end{tabular}




\section{Analysis of the causes of death}

Pulmonary complications are the commonest cause of death in patients with cervical spine trauma, constituting more than 75 per cent of deaths. The most frequent pathology is diffuse lung inflammation, which is usually a consequence of suppurative bronchitis. Primary respiratory insufficiency, occurring after spinal cord trauma in a high cervical segment, causes diaphragmatic paralysis.

The great majority of deaths occur during the first three weeks following trauma (more than 70 per cent) and are usually a consequence of the pathological state developing in the aforementioned vegetative and respiratory systems. At a later stage, patients may die from pulmonary artery embolism. After a period of several months the commonest cause of death is a chronic disturbance in the urinary system resulting in renal insufficiency.

As has already been shown, mortality increases with the age of patients. This relationship appears in the group of pulmonary and renal death causes. It is clear that these pathological changes resulting from spinal cord trauma, are more easily controlled in young persons than in patients of advanced years because post-traumatic changes overlap changes in organs affected by age and previous diseases.

It is necessary to state that each of the patients over 50 years of age (whose treatment ended with failure) had suffered chronic general diseases which had been treated for many years; this influenced the high percentage mortality among 50-year-old patients. The majority of those coming from a rural environment were characterised by neglected health. The heavy physical work done by these persons caused biological deterioration which enhanced their real age.

\section{Discussion}

The mortality among persons with cervical spine trauma treated in our Institute is relatively high, amounting to 17 per cent, and in those with complete spinal cord injuries 33 per cent. Comparing our mortality with that contained in the literature, we believe that account should be taken of these specific peculiarities of our clinical material:

(a) the large number of patients treated with complete or severe partial spinal cord injury;

(b) the significant percentage of patients advanced in years, and being, in the majority of cases, biologically older than their real age and already suffering from systemic diseases;

(c) the large group of patients with high-level spinal injury (above $\mathrm{C}_{5}$ ); these patients were admitted to our Institute with evidence of paralysis of the phrenic nerve and developing primary respiratory insufficiency;

(d) the extensive injuries of other organs, especially head and chest, which may influence the ultimate prognosis.

Taking the above data into consideration, it can be appreciated how difficult it is to obtain better results in respect of mortality. We believe that the improvement of health care facilities that has occurred recently, particularly in rural areas, together with better first aid services, will be decisive in causing a decrease of mortality. Clinical experiences should show in the near future a considerable improvement in the results of treatment. 


\section{Conclusions}

I. The highest rate of mortality occurred in patients:

(a) advanced in years (over 65 years of age);

(b) with spinal injury at $\mathrm{C}_{3}-\mathrm{C}_{4}$ level;

(c) with complete spinal cord injury;

2. Principal factors causing the high percentage of deaths in our clinical material are:

(a) a considerable number of patients with complete spinal cord injury (52 per cent);

(b) a great number of persons with spinal injury above $\mathrm{C}_{5}$ (30 per cent);

(c) a considerable percentage of patients advanced in years with chronic disease of internal organs;

(d) concomitant injuries of other parts of the body, especially of the head and chest.

3. Improvement of health care in the country and progress in the methods of treatment of spinal cord injuries should produce a further decrease in mortality.

\section{RÉSUMÉ}

On a présenté une analyse de I67 décès constatés chez les I,000 malades avec le trauma de la colonne cervicale pendant le période post-traumatique précoce, soignés dans la Clinique de Réhabilitation de Konstancin.

Le grand pour-cent de décès fait dépendre de: le traitement d'une grande nombre des malades gériatriques épuisés des autres graves maladies, une grande groupe des malades avec une lésion de la moelle totale et profond, une incidence fréquente de lésion dans le haut segment de la colonne cervicale (ci-dessus $\mathrm{C}_{5}$ ), et aussi chez pas rarement constaté des lésions associés des autres organes, surtout du crâne et du thorax.

Les auteurs sont persuadés que la diminuation de la létalité peut être réalisée dans les prochaines années grâce à l'amélioration de l'assistance médicale à la campagne, aussi avec le progrès dans le traitement des lésions de la moelle.

\section{ZUSAMMENFASSUNG}

Im Bericht wurden Analysen von I67 Todesfällen unter I,000 Kranken mit Beschädigung der Halswirbelsäule festgestellt. Sie betreffen Kranke-die in kurzer Zeitspanne nach der Verletzung in Behandlung der Rehabilitationsklinik in Konstan-cin hiraufgenommen wurden.

Der hohe Prozent von Todesfällen ist bedingt: durch das hohe Alter vieler dieser Patienten, welche dazu noch durch andere schwere allgemeine Krankheiten belästigt waren. Eine grosse Gruppe dieser Kranken hatten eine tiefe und völlige Beschädigung des Rückenmarks, insbensondere des hohen Zervikalsegments (über C5). Nicht selten wurden nebenbei Beschädigung anderer Organe festgestellt, insbesondere des Schädels und des Brustkorbs.

Die Verfasser geben Ausdruck ihrer Überzeugung, dass die-in den letzten Jahren durchgeführte Besserung der Vehältnisse der Gesundheitspflege auf dem Lande samt dem Vortschritt im Behandeln der Traumas des Rückenmarks, einen beträchtlichen Rückgang der Sterblichkeit in den nächsten Jahren ermöglichen werden.

\section{REFERENCES}

ChoróbSKi J. (1953). Sympathetic and parasympathetic system. PZWL, Warszawa.

Frankel, H. L., Hancock, D. O., Hyslop, G., Melzak, J., Michealis, L. S., Ungar, G. H., Vernon, J. D. S., WALSh, J. J. (I969). The value of postural reduction in the 
initial management of closed injuries of the spine with paraplegia and tetraplegia. Paraplegia, 7, I79-192.

HAfTEK, J., Chromiec, E., Kiwerski, J. (1968). Prevention and treatment of pulmonary complications in acute trauma of the cervical spinal cord. In: Spinal cord compensation. PZWL-Warszawa, pp. I07-I I4.

Rossier, A. C., Bors, E. (I965). Problems of the aged with spinal cord injuries. Paraplegia, 3, 34-45.

YASHON, D. (1978). Spinal Injury. Appleton-Century-Crofts. New York. 